\title{
The Influence Of Pre-Operative Health Education To The Self-Concept Improvement On Femoral Fracture Patientsat Haji Medan Hospital Of North Sumatera Government In 2021
}

\author{
Marniati $^{{ }^{*}}$, Sri Misleini ${ }^{2}$, Zuidah $^{3}$, Kamaliah Ainun ${ }^{4}$, Kristina $^{5}$, Sukma Yunita ${ }^{6}$, Yetti Fauziah ${ }^{7}$, \\ Niasty Lasmy Zaen ${ }^{8}$, Fransiska Riati Nova Simbolon ${ }^{9}$, Dewi Ramadani ${ }^{10}$ \\ 1,2,3,4,5,6,7,8,9,10 Health Faculty, Indonesian Ubudiyah University \\ * Corresponding author: \\ Email : marniati@uui.ac.id
}

\begin{abstract}
Femoral fracture is continuity disconnected of the femoral shaft occurring due to direct trauma (traffic accidents, falls from the height), and it is usually experienced by the adult males. Fractures of this area affects heavy bleeding and impacts the shock. This study aimed to find out whether there is the influence of pre-operative health education to the self-concept improvement on femoral fracture patients At Haji Medan Hospital of North Sumatera Government in 2021The research type used was Quasi Experiment design. This study used one group pre-test and post-test design. The research location was at Haji Medan Hospital of North Sumatera Government in 2021. The population were all femoral fracture patients having treatment at Haji Medan Hospital of North Sumatera Government. Based on RSU Haji Medical record data, there were 30 patients in July-December 2020. The sampling technique was purposive sampling. The total sample were 20 femoral patients.The outputs described that there is a significant correlation between pre operative health education and self-concept improvement on femoral fracture patients At Haji Medan Hospital of North Sumatera Government in 2021. The value is $p<\alpha$ as $0.000<0.05$. It is proved that pre operative health education to be effective in improving self-concept on femoral fracture patients At Haji Medan Hospital of North Sumatera Government in 2021.The suggestion of the study is required to be applied by medical practitioner in the hospital, particularly the nurses providing the nursing care to the femoral fracture patients and support the patients in overcoming the anxiety of the disease by maximizing the existing social supports.
\end{abstract}

Keywords: Health Education, Self-Concept

\section{INTRODUCTION}

\section{Background}

A fracture is a normal bone continuity disorder (Black 2014). Fracture is are the condition that bone tissue and or cartilage continuity is completely or partially disturbed by pressure or osteoporosis (Smeltzer \& Bare, 2013). Fracture is a cartilage continuity loss both total and partial, the main causes are both the bond and the surrounding soft tissue traumatic or physical exertion (Helmi, 2018).Femoral fracture is continuity disconnected of the femoral shaft occurring due to direct trauma (traffic accidents, falls from the height), and it is usually experienced by the adult males. Fractures of this area affects heavy bleeding and impacts the shock (FKUI, 2016). The fracture cause is the hard pressure or hit directly received by the bone. The pressure is caused by a sudden and excessive force of hitting, crushing, bending, twisting or pulling. The closed fracture is the fracture occurring on the intact skin while the open fracture occurs on translucent cavities. The accident or fall disadvantages can be interpreted by the physically damages consisting of burns, disability, and fracture as femoral fracture. The fracture impacts result pain and physical mobility disorder affecting the patient have no self-concept and long-term anxiety. If the fracture does not $h$ recover, it can be the part amputations. In addition, it can be contaminated by microorganisms and impacting the infection (Muttaqin, 2018).

The nurses are require in this condition in improving the femoral fracture patients' self-concept. They can provide the nursing care focusing o musculoskeletal system and support the patients to be motivated in recovering process. They are also required in reducing the anxiety and improving the self-concept (Smeltzer \& Bare, 2010)The output of Basic health Research in 2013 mentioned that the traffic accidents in the Central Java area causing $6.2 \%$ fractures. According to Desiartama \& Aryana (2017), femoral fracture was the 
highest and the most frequent as 39\% followed by humerus fractures (15\%), tibia and fibula fractures (11\%). Data from the Medan Health Institution explained that the traffic accidents were caused by car, motorcycle, or recreational vehicle $(62.6 \%)$ and fell $(37.3 \%)$ and the majority were men $(63.8 \%) .5 \%$ Peak age distribution in femoral fractures is in adults (15-34 years) and the elderly (over 70 years) (Dinkes Kota Medan, 2019).Fracture cases at the Haji Medan Hospital Medan, North Sumatra Government occupy the top 10 diseases in the first semester of 2018 . There were $42 \%$ femoral fracture cases, $16 \%$ cruris fractures cases, and $21 \%$ clavicle fractures cases. The causes of fractures found at Haji Medan Hospital Medan, North Sumatra Government are traffic accidents, falls from a height, work accidents and sports. The fractures impacts are extremely pain, disability affecting a lack of self-concept.

The nurses have the longest contact in treating the patients. The nurses' involvements in recovering efforts become very important. A nurse is required to realize the patients' condition and needs. One of the nurses' tasks is pre-operative patient care. Preoperative treatment can reduce postoperative risk. One of the nurses' priorities in this period is reducing patient anxiety or patient self-concept of surgery (Smeltzer \& Bare, 2017).The nurses are one of the health workers interacting the most with the patients. They have the obligation in supporting the patients to prepare Physic and mental for surgery including providing health education. The nurses require good communication skills. The attitude and behavior of nurses support in developing the patients self-confident. Every interaction with the patients should support the patient to fell that surroundings care of the patients' safety. One of the nurses' effort is paying attention to the smallest detail of patients' treatment. The nurses should listen all of the patients' compalaints (Widodo, 2016).There are several different methods in supporting the patients in preoperative phases. Several activity implemented are by providing health education, spirituality, patient assistance, and psychiatrist consultation. More support from family and surrounding, the more support the patients (Smith \& Pitaway, 2017).

The health education is required to provide to the patients in preoperative phase. Health education is an activity in delivering the health messages to the community, group or individual. It is expected that by receiving the health information, the patient and family receive better information knowledge to improve their self-concept (Notoatmojo, 2017).A self-concept is not developed at birth, for it is learned from a unique experiences of a person himself in the relation to the close people and world reality. In addition to selfconcept, the other important effort is system, family, and surrounding supports (natural, E, 2016). Fracture patients has no self-confident due to their condition, the self-concept experienced by fracture patients is a lack of self-image (body image) of the patients' looks and size, the disorder of body function due to the disability (Muttaqin, 2018)The personal unconfident of the patients affect that they do not want to treat or operate. This condition will impact the patients' confident, capability and productivity. If the patients were forced to retire to continue the recovery treatment, they can fell bereavement and disconnected to others. The health education is required to change the wrong self-concept of the fracture patients (Muttaqin, 2018)

Health education on preoperative phase is expected to be implemented by the patients on postoperative phase. It provides a systematic and structured format by teaching and learning principles. It has a positive influence on the patients' recovery, and improve the patient's self-concept (Sarason, 2017). One of the efforts in supporting self-concept disorders of the patients is by providing health education. Health education is provided In order to prepare the patients can accept their current condition, love and respect themselves and then creating healthy attitude. Attitude is habit and the habit should be developed and learned. The healthy attitudes can be created and habituated in the daily activities in creating a positive self-concept. The family support is also required to improve patient's self-confidence (Sarason, 2017).Due to the above phenomena, femoral fractures impacts many changes to the patients. The changes are physical changes Affecting selfconcept reduction i.e. feeling uncomfortable, not respected; psychological changes i.e. Feeling alienated, not respected, and not acceptance of personal; social changes, and spiritual changes. The impact can reduce the life quality of life of patients as self-concept changes (Keliat, 1992)

.One of the methods to solve self-concept reduction on fracture patients is improving the self-concept. Self-concept provided in order to develop the patients in accepting their conditions and respecting themselves. It will create a healthy attitude of the fracture patients (Copel, 2017). Attitude is thought habit and it can be created and learned by the patients. The healthy attitudes can be created and habituated in the 
daily activities in creating a positive self-concept. In addition, the family support is also required to improve patient's self-confidence (Sarason, 2018).The Haji Medan Hospital of North Sumatra Government is one of the referral patients that treated 35 femoral fracture patients in 2020. Based on the initial study output, there were 10 femoral fracture. 7 patients had no preoperative health education. It resulted that at the surgery phase, the patients' lost their self-concept including unconfident and feeling sad of the condition.Due to the previous background, the researchers were interested in observing about influence of pre-operative health education to the self-concept improvement on femoral fracture patients At Haji Medan Hospital of North Sumatera Government in 2021.

\section{The Question Formulation}

Due to the previous background, the researcher can formulate the question of this study. The question is "are there any influences of pre-operative health education to the self-concept improvement on femoral fracture patients At Haji Medan Hospital of North Sumatera Government in 2021?'

\section{RESEARCH METHOD}

The research type used was Quasi Experiment design. This study used one group pre-test and post-test design. The research location was at Haji Medan Hospital of North Sumatera Government in 2021. The population were all femoral fracture patients having treatment at Haji Medan Hospital of North Sumatera Government. Based on RSU Haji Medical record data, there were 30 patients in July- December 2020. The sampling technique was purposive sampling. The total sample were 20 femoral fracture patients.

\section{RESULT AND DISCUSSION}

Research General Description

Haji Medan General Hospital of North Sumatra Government is a class B hospital used as main health referral hospital in North Sumatra and its surroundings area. The total area of Haji Medan Hospital is $60,002 \mathrm{M}^{2}$ and the total building area is $13,837 \mathrm{M}^{2}$. The Haji Medan General Hospital of North Sumatra Province is located on Rs. Haji Medan Estate Medan Street, Deli Serdang District and in the border of Medan.The vision of Haji Medan Hospital is to be a superior hospital and referral center that is Islamic, environmental friendly, competitiveness both national and international standard.The missions of Haji Medan Hospital include: 1. Improving the professionalism and integrity and religious competence of human resources at the Medan Haji General Hospital, North Sumatra Province, 2. Improving the facilities and infrastructure quality of Haji Medan General Hospital based on national and international standards using the comfort and safety principles, 3 .

Improving the prosperity of human resources at the Haji Medan General Hospital, North Sumatra Province through the Public Service Institution Financial Management Pattern, 4. Improving health service range facilities, 5. Improve the quality of transparent, clean, friendly, safe and comfortable services and go green healthy environment. Haji Medan Hospital has various types of medical services. Medical services at Haji Medan Hospital consist of 20 polyclinics, i.e. surgery, pediatrics, internal disease, obstetrics and gynecology, eyes, skin and venereal disease, neurology, psychiatry, lung disease, dentistry, ENT, cardiology, physiotherapy, orthopedics, TB dots, VCT voluntary counseling and testing, hemodialysis and emergency installation. The number of bed facilities at Haji Medan Hospital are 245 beds consisting of 2 beds for suite rooms, 2 beds for super VIP rooms, 27 beds for VIP B rooms, 68 beds for class III adult, 16 beds for class III kid, 9 beds for PICU/NICU rooms, 9 beds for baby rooms, 29 beds for class II rooms, 23 beds for class I room, 44 beds for COVID isolation rooms, 10 beds for hemodialysis rooms, 12 beds for ICU, and 1 operating room.

\section{Univariate Analysis}

\subsubsection{Respondent Characteristic}

Respondent characteristics in hemodialysis unit at Haji Medan Hospital of North Sumatra Province in 2021 were categorized by age, educational background and job description. The Respondent characteristics can be detail described on Table 4.1 below: 
Tabel 4.1.Respondent Characteristics in Hemodialysis Unit at

Haji Medan Hospital of North Sumatra Province in 2021

\begin{tabular}{|c|c|c|c|}
\hline No & Demographics Data & Frequency & Percentage (\%) \\
\hline \multirow[t]{5}{*}{1} & Age & & \\
\hline & 20-30 years old & 7 & 35.0 \\
\hline & $31-40$ years old & 9 & 45.0 \\
\hline & $>40$ years old & 4 & 20.0 \\
\hline & TOTAL & 20 & 100 \\
\hline \multirow[t]{4}{*}{2} & Gender & & \\
\hline & Male & 13 & 65.0 \\
\hline & Female & 7 & 35.0 \\
\hline & Jumlah & 20 & 100 \\
\hline No & Demographics Data & Frequency & Percentage (\%) \\
\hline \multirow[t]{6}{*}{3} & Educational Background & & \\
\hline & Elementary School & - & - \\
\hline & Junior High School & 7 & 35.0 \\
\hline & Senior High School & 10 & 50.0 \\
\hline & University & 3 & 15.0 \\
\hline & Total & 20 & 100 \\
\hline \multirow[t]{5}{*}{4} & Job Description & & \\
\hline & Housewife & 6 & 30.0 \\
\hline & Entrepreneur & 11 & 55.0 \\
\hline & Government Staff & 3 & 15.0 \\
\hline & Total & 20 & 100 \\
\hline
\end{tabular}

Based on table 4.1, most of the femoral fracture patients at Haji Medan Hospital of North Sumatra Province in 2021 have the age between 31-40 years as 9 respondents (45.0\%). The most genders are male as 13 respondents $(65.0 \%)$. The most of respondents have the educational background of senior high school as 10 respondents (50\%), and entrepreneurs as job description, i.e. 11 respondents $(55.0 \%)$.

4.2.2 The self-concept on femoral fracture patients of pre pre-operative health education At Haji Medan Hospital of North Sumatera Government in 2021

The data of self-concept on femoral fracture patients of pre pre-operative health education At Haji Medan Hospital of North Sumatera Government in 2021 can be described in Tabel 4.2 below:

Tabel 4.2. The self-concept on femoral fracture patients of pre pre-operative health education At Haji Medan Hospital of North Sumatera Government in 2021

\begin{tabular}{ccc}
\hline $\begin{array}{c}\text { Self-Concept of Femoral Fracture Patients } \\
\text { (Pre) }\end{array}$ & Frequency & $\%$ \\
\hline High & 3 & 15.0 \\
Moderate & 10 & 50.0 \\
Low & 7 & 35.0 \\
\hline Total & 20 & 100 \\
\hline
\end{tabular}

Table 4.2 of self-concept on femoral fracture patients of pre pre-operative health education At Haji Medan Hospital of North Sumatera Government in 2021 informs that the majority of patients on the pre-test are moderate as 10 respondents $(50.0 \%)$.

4.2.3 The self-concept on femoral fracture patients of post pre-operative health education At Haji Medan Hospital of North Sumatera Government in 2021

The data of self-concept on femoral fracture patients of post pre-operative health education At Haji Medan Hospital of North Sumatera Government in 2021 can be explained in Tabel 4.3 below.

Tabel 4.3.The self-concept on femoral fracture patients of post pre-operative health education At Haji Medan Hospital of North Sumatera Government in 2021

\begin{tabular}{ccc}
\hline $\begin{array}{c}\text { Self-Concept of Femoral Fracture Patients } \\
\text { (Post) }\end{array}$ & Frequency & $\%$ \\
\hline High & 11 & 55.0 \\
Moderate & 8 & 40.0 \\
Low & 1 & 5.0 \\
\hline Total & 20 & 100 \\
\hline
\end{tabular}


Table 4.3 of self-concept on femoral fracture patients of post pre-operative health education At Haji Medan Hospital of North Sumatera Government in 2021 informs that the majority of patients on the pre-test are high as 11 respondents $(55.0 \%)$.

4.2.4 The influence of pre-operative health education to the self-concept improvement on femoral fracture patients At Haji Medan Hospital of North Sumatera Government in 2021

The statistical test of the influence of pre-operative health education to the self-concept improvement on femoral fracture patients At Haji Medan Hospital of North Sumatera Government in 2021 can be described as Table 4.4.

Tabel 4.4.The influence of pre-operative health education to the self-concept improvement on femoral fracture patients At Haji Medan Hospital of North Sumatera Government in 2021

\begin{tabular}{|c|c|c|c|c|c|}
\hline \multirow{3}{*}{$\begin{array}{l}\text { Self-Concept of Femoral } \\
\text { Fracture Patients }\end{array}$} & \multicolumn{2}{|c|}{ Health Education } & \multirow{2}{*}{ Ranking Change } & & \multirow{2}{*}{$p$ value } \\
\hline & Pre & Post & & & \\
\hline & $\mathrm{F}$ & $\mathrm{F}$ & & $\mathrm{F}$ & \\
\hline - High & 3 & 11 & Positive Ranking & 0 & \\
\hline - Moderate & 10 & 8 & Negative Ranking & 13 & $0,000 *$ \\
\hline - Low & 7 & 1 & Ties & 7 & \\
\hline
\end{tabular}

Description: a) Wilcoxon test

Self-Concept of Femoral Fracture Patients:

- Negative ranking is the change of previous and after self-concept conditions from "Low" category to "High' category

- Positive ranking is the change of previous and after self-concept conditions from "High" category to "Low' category

- Ties means that there is no change of self-concept of the previous and after conditions.

Table 4.4 explains that the patients self-concept of before and after health education have changed. The patients' self-concept of before health education results that 3 respondents have high level and it improve to 11 respondents after health education. While there were 8 respondents in moderate level pre health education and it decreases to 8 respondents after health education. The outputs of statistical tests using the Wilcoxon test inform that $\mathrm{p}<\alpha$ as $0.000<0.05$ meaning that $\mathrm{H}_{0}$ is rejected. There is a significant correlation between pre-operative health education and the self-concept improvement on femoral fracture patients the self-concept improvement on femoral fracture patients at the Haji Hospital Medan, North Sumatra Government in 2021. The output explains is proved that pre-operative health education can be effective to the self-concept improvement on femoral fracture patients at the Haji Hospital Medan, North Sumatra Government in 2021

\section{Discussion}

4.3.1 The self-concept on femoral fracture patients of pre pre-operative health education At Haji Medan Hospital of North Sumatera Government in 2021

The output of self-concept on femoral fracture patients of pre pre-operative health education At Haji Medan Hospital of North Sumatera Government in 2021 explain that the majority of patients on the pre-test are moderate as 10 respondents $(50.0 \%)$. These output is in line with the theory mentioning that the individuals with femoral fracture is not only facing self-image disruption due to physical changes but also feeling fear, anxiety with their condition, anger, and even depression. He feels useless with the physical disorder. There are several changes i.e. the change of household role due to the work limitation, the social relation is different compared to before fracture, and cognitive capability reduction (Potter and Perry, 2015).The symptoms of body image disorder including the change and lost of the the body parts i.e. structure, shape, or function. The patients reject this changes, feel shock, anger, loss, fear, and cannot accept the conditions. If the body image disorder does not solve, it will create the psychosocial problems including low confident, social isolation, suicide risk and mental disorders (Keliat, 2013).Self-concept of fracture patient is the patient's perspective in describing his personality.

This condition make patient feel less complete in appreciating himself. He feels anxious and requires social supports. The output of the study mentions that the higher self-concept, the lower the anxiety feeling and vice versa. The higher the social support, the lower the anxiety, and vice versa. There is correlation 
between self-concept and social support to anxiety in confronting the patient's pain. (Kurniawati, 2012)The output of the research carried out by f Hariana, Sugi and Yessi Ariani (2007) mentioned that the adaptation response of lower extremity fractures patients during the treatment at $\mathrm{H}$. Adam Malik Hospital Medan and RSU Dr. Pirngadi Medan resulting from 12 respondents, there were 50\% respondents feeling less confident to communicate with others, $33.4 \%$ respondents feeling something bad condition will impact their fracture leg, and $41.7 \%$ respondents feeling more sensitive.Based on the above outputs, it is required to the nurses' role in conducting not only psychological assessments (emotional responses) of patients but also physical condition of being anxiety and shame on the physical condition. The nurse review the patients' conditions by observing self-concept patients' level, reviewing patient's body image and ideal, reviewing physical disorders and identity disorders by reviewing the patient's perception and the patient's behavior (Nurhalimah, 2016).

4.3.2 The self-concept on femoral fracture patients of post pre-operative health education At Haji Medan Hospital of North Sumatera Government in 2021

The output of self-concept on femoral fracture patients of post pre-operative health education At Haji Medan Hospital of North Sumatera Government in 2021 informs that the majority of patients on the pretest are high as 11 respondents (55.0\%). It proves that self-concept on femoral fracture patients of post preoperative health education is improved.According to the theory, a person with a femoral fracture accepting and feeling comfortable with the condition develops himself to have more spirit in running the life and recovering. While the individual not accepting and feeling uncomfortable with the condition will worsen both physical and psychological conditions.

It is very important for femoral fractures patients to have a positive self-concept for healing, preventing psychological disorders such as depression, for the future better survival condition (Sutrisno, 2017).Health education of the self-concept on femoral fracture patients include discussing about the patients feeling, identifying the usual roles in the family, providing positive reinforcement, involving the family to support patients in identifying the realistic and the role change. The nursing implementation is carried out in accordance with Stuart's (2013) theory. The role tension is related to the expected role or position and the individual and frustrated condition.

4.3.3 The influence of pre-operative health education to the self-concept improvement on femoral fracture patients At Haji Medan Hospital of North Sumatera Government in 2021

The output explains that the patients self-concept of before and after health education have changed. The patients' self-concept of before health education results that 3 respondents have high level and it improve to 11 respondents after health education. While there were 8 respondents in moderate level pre health education and it decreases to 8 respondents after health education. The outputs of statistical tests using the Wilcoxon test inform that $\mathrm{p}<\alpha$ as $0.000<0.05$ meaning that $\mathrm{H}_{0}$ is rejected. There is a significant correlation between pre-operative health education and the self-concept improvement on femoral fracture patients the self-concept improvement on femoral fracture patients at the Haji Hospital Medan, North Sumatra Government in 2021. The output explains is proved that pre-operative health education can be effective to the self-concept improvement on femoral fracture patients at the Haji Hospital Medan, North Sumatra Government in 2021According to Wagner, et al (2013), interventions implemented for the of body image disorders diagnosis can support the patients in discussing changes caused by fracture, determining the actual changes sustainability or function level, discussing stressors affecting self-image related to disease conditions, determining patient and family perceptions related to self-image and reality changes, identifying actions of appearance improvement, checking negative perceptions, exploring previous success achievements, motivating the families patients supports, and creating positive statements about the patient.

According to Wagner, et al (2013), health education on femoral fracture patients' self-concept aims to accept the self-situational acceptance, set realistic goals, plan the realistic future, being realistic in treatment, develop the roles, accept the role change in the positive condition, and being able to accept changes.Self-concept and health perception are closely related each other. The Individual accepting the health education can improve his self-concept. While the individuals not having confident to his physical and health conditions and not believing the treatment can receive the negative concept (Potter and Perry, 
2015).According to the researcher, health education of the femoral fracture patients' self-concept is proven in improving the self-concept on femoral fracture patients. Individuals with a positive self-concept become realistic in accepting the pain, more optimistic, more confidence, trusting the treatment, more appreciating himself and positive thinking of the condition. This occurs because of effective coping and there is social support (support system) from the family, friends, co-workers, and others. The individual also has a good spirituality level of spirituality in accepting and positive thinking of the God, considering that he can pass the condition. This kind of individual have the strong motivation to recover even they feel pain. (Young, 2017).

\section{CONCLUSION AND SUGGESTION}

\section{Conclusion}

According to the above explaination of the study outputs and discussion, it can be conclude as below:

1. The output of self-concept on femoral fracture patients of pre pre-operative health education At Haji Medan Hospital of North Sumatera Government in 2021 explain that the majority of patients on the pre-test are moderate as 10 respondents $(50.0 \%)$.

2. The output of self-concept on femoral fracture patients of post pre-operative health education At Haji Medan Hospital of North Sumatera Government in 2021 informs that the majority of patients on the pretest are high as 11 respondents $(55.0 \%)$.

3. There is a significant correlation between pre-operative health education and the self-concept improvement on femoral fracture patients the self-concept improvement on femoral fracture patients at the Haji Hospital Medan, North Sumatra Government in 2021 since $p<\alpha$ as $0.000<0.05$. The output explains is proved that pre-operative health education can be effective to the self-concept improvement on femoral fracture patients at the Haji Hospital Medan, North Sumatra Government in 2021

\section{Suggestion}

Based on the study outputs, the researchers require to give several suggestion as below:

\section{For medical staff}

It is expected that the medical staff in the hospital, particularly the nurses provide the nursing councelling to femoral fracture patients, support them in solving their fear of the pain and maximize the existing social supports

\section{For respondents}

The patients are expected to utilize the existing social supports in facing their pain so they can handle the fear. The maximal supports from the family and social are important in supported the patient in facing their pain.

\section{For the next researchers}

It is expected to the next researchers to develop the study by using other variables affecting selfconcept on femoral fracture patients that have not reserached here including situation condition, educational level, and individual characteristic

\section{REFERENCES}

[1] Febrina Angraini S, Tahun 2018, The influence of preoperative health education of the self-concept improvement on femoral fracture patients At Haji Adam Malik Hispital Medan in 2018

[2] Grace, A.P \& Borley, R.N. (2017). At a Glance of Surgery, Third Edition. Jakarta: Erlangga

[3] Gray Henry, Gray's Anatomy of The Human Body, The Femur, www.bartleby.com, 2-14.

[4] Helmi, N.Z., (2018). Textbook of Musculoskeletal Disorders. Jakarta : EGC

[5] Keliat, B. A. (2000). Self - Concept Disorder. Jakarta: EGC.

[6] Koval J. Kenneth, Zuckerman D. Joseph, Handbook Of Fractures, 3rd Edition, Lippincot Williams \& Wilkins, 2006, 347-354.

[7] Kozier, B., Glenora Erb., Ausrey B., dan Shirlee J.S. (2004). Fundamentals of Nursing: Concepts, Process, and Practice. New Jersey: Pearson Education

[8] Potter, P.A., dan Perry, A.G. (2005). Nursing Fundamental: concept, process, and practice. Forth Edition. (Devi Yulianti and Monica Ester, translated). The resource book was published in 1997. St. Louis: Mosby. 
[9] Notoatmodjo, S. (2010). The Health Research Methodology. Jakarta: Rineka Cipta.

[10] Sarason, 2017, Priciple and Practice of Psychiatric Nursing 4 edition. St Louis the CV. Mosby Company.

[11] Stuart, G.W., Michele T. L. (2010). Smeltzer, S.C; \& Bare, B.G. (2017). Textbook of Surgery Medical Nursing. Jakarta: EGC

[12] Smeltzer, Suzanne C \& Bare, Brenda G. Textbook of Surgery Medical Nursing of Brunner and Suddarth (Ed.8, vol.1,2), translated by Agung Waluyo, dkk., EGC Jakarta, 2000, 89-91

[13] Sutrisno, A. (2007). Stroke You Must Know Before You Get It. Jakarta: Gramedia Pustaka Utama.

[14] Swiontkowski MF, Stovitz SD. Manual of Orthopaedics. 6th Edition, Lippincott Williams \& Wilkins, 2001, 45-47.

[15] Thompson C. John, Netter H. Frank, Netter's Concise Orthopaedic Anatomy, 2nd Edition, Saunders Elsevier, Philadelphia, 2002, 265-270.

[16] World Stroke Organization. Stroke. Accessed on 21 September 2020, at 20.00 Wib, fromwww.worldstroke.org/ Young,

[17] Young, C., dan Cyndie K. (2007). Spirituality, Health and Healing. Medan: Bina Media Perintis. 